\section{Aquaculture}

Volume 267, Issues 1-4, 3 July 2007, Pages 20-30

http://dx.doi.org/10.1016/i.aquaculture.2007.01.005

(C) 2007 Elsevier
Archimer, archive institutionnelle de l'Ifremer http://www.ifremer.fr/docelec/

\title{
Live yeasts in the gut: Natural occurrence, dietary introduction, and their effects on fish health and development
}

\author{
F.J. Gatesoupe
}

INRA-Ifremer, UMR 1067 NuAGe, Nutrition, Aquaculture et Génomique, Ifremer, Centre de Brest, BP 70, 29280

Plouzané, France ; joel.gatesoupe@ifremer.fr

\begin{abstract}
This minireview summarizes the present state of knowledge concerning the importance of yeasts in fish gut. Yeasts have been commonly isolated in the gastrointestinal tract, and high population densities were sometimes noted in healthy fish, but the data were quite variable in terms of colony counts and taxonomical diversity. Rhodotorula sp. seemed relatively frequent in both marine and freshwater fish, and Debaryomyces hansenii has been found to be dominant in rainbow trout. Some other dominant strains have been described, such as Metschnikowia zobelii, Trichosporon cutaneum, and Candida tropicalis in marine fish, and Candida sp., Saccharomyces cerevisiae, and Leucosporidium sp. in rainbow trout. The natural proliferation of yeasts in fish mucus may be generally considered as commensalism, in spite of a few cases of pathological infections mainly due to opportunistic strains.

Several strains were documented to settle and grow in fish intestine after experimental introduction, particularly $S$. cerevisiae and $D$. hansenii in rainbow trout. There have been a few instances of competition among yeasts in fish intestine, while the effect of yeast on associated bacteria is still unclear.

Yeasts can stimulate the immune response in fish. B-glucans is likely the most important compound in this regard, but some other cell-wall components or soluble factors may also play a role. Both cellular and humoral responses have been educed by dietary yeast, depending on the experimental conditions. Other benefits may be expected for the host, especially the intestinal colonisation of early feeding fry with yeast, which may have some effect on development, e.g. by accelerating the maturation of the digestive system. In older fish, dietary yeast may stimulate metabolism and growth. Such beneficial effects need to be further investigated, either in cases of natural colonisation or after dietary introduction, while trying to elucidate the mode of action, and determine whether cellular viability is a prerequisite for efficacy.
\end{abstract}

Keywords: yeast; probiotics; gastrointestinal microbiota; gut maturation; growth promotion; immune system 


\section{Introduction}

Yeasts are ubiquitous microorganisms, which disseminate with animals, air and water currents, and which can grow in various environments where organic substrates are available. Their presence has been noted in fish guts for some time in wild, as well as farmed animals, but this natural occurrence has been generally considered as incidental. Industrial yeast is commonly used in aquaculture, either alive to feed live food organisms, or after processing, as a feed ingredient (Stones and Mills, 2004). Some extracts, like $\beta$-glucans, are used as immuno-stimulants, and more recently, living yeasts have been proposed as probiotics. It may be time to inventory the state of knowledge concerning yeasts in fish intestinal microbiota, with the view to evaluate their possible effects on fish health and metabolism, and ways to monitor natural and artificial colonisation.

\section{Natural occurrence in healthy fish}

The investigation of yeasts as components of fish microbiota does not necessarily require specific culture media, and many microbiological broths and agars are suitable. There are however dedicated media whose selectivity may be improved by adding antibiotics. It appears that yeasts can constitute a significant part of the microbiota in fish gut (Table 1). In a few cases, yeasts may be more numerous than cultivable bacteria, like in the deep-sea eel Synaphobranchus kaupi (Ohwada et al., 1980), or in mature masu salmon in freshwater (Yoshimizu et al., 1976b). These examples seem exceptional, but yeast may be of physiological importance even when accounting for less than $1 \%$ of the total microbial isolates. It should be kept in mind that yeasts have cell volumes that may be larger than those of bacteria by a hundredfold. For instance, the cell volume of brewer's yeast averages 200$300 \mu^{3}$ (Cahill et al., 1999), while growing cells of Pseudomonas fluorescens reach a volume of ca. $1 \mu \mathrm{m}^{3}$ (Wilhelm et al., 1998). Therefore, an apparently negligible number of colony forming units (CFU) may correspond to a population size sufficient to act upon the host. For instance, anticipating the effects of live yeasts on fish metabolism (section 7), Debaryomyces hansenii was efficient in European sea bass larvae at $10^{4} \mathrm{CFU} \mathrm{g} \mathrm{g}^{-1}$, on a body weight basis (Tovar et al., 2002), whereas the bacterial counts may range from $10^{7}$ to $10^{9}$ CFU g ${ }^{-1}$ (Gatesoupe et al., 1997). It remains that highly variable levels of the natural yeast population have been observed, from below the detection threshold up to $10^{7} \mathrm{CFU} \mathrm{g}^{-1}$, on a gut content basis (Table 1).

This variability appeared also when the yeasts were characterised. Valente et al. (1999) emphasized the difficulty to define species of microorganisms, and this seemed particularly arduous with yeast. The Merriam-Webster Medical Dictionary spoke of "a unicellular chiefly ascomycetous fungus (as of the family Saccharomycetaceae) that has usually little or no mycelium, that typically reproduces asexually by budding”. The morphological determination may be sometimes difficult, when the budding cells form pseudomycelium. The classification of yeasts has been constantly undergoing change, based first on morphological and physiological criteria (Pelczar and Reid, 1972), then on the development of molecular taxonomy (Valente et al., 1999). Yeasts occurring in fish microbiota may be classified in two distinct phyla of the fungal kingdom: Ascomycota, among which Saccharomycetaceae are probably the most important family, but also Basidiomycota, which include the genus Rhodotorula - these red yeasts are commonly observed in fish microbiota. Table 2 summarises tentatively the genera that have been reported in fish intestine. The classification was based on Patterson and McGinnis (2006), with complementary information from Ericksson (2006) and NCBI Taxonomy Browser (Wheeler et al., 2000). It is noteworthy that 
the latter database proposed several orders for strains characterised as Cryptococcus, Rhodotorula, and Sporobolomyces, unlike Patterson and McGinnis (2006). Some phylogenetic revision among these genera may therefore be expected (Biswas et al., 2001; Takashima et al., 2001; Gadanho and Sampaio, 2002). This database was also used to identify the genera of four strains isolated from rainbow trout, Yarrowia sp., Kluyveromyces sp., Filobasidium sp., and Bulleromyces sp. (Gatesoupe, unpublished), by using partial sequences of PCR amplicons from primers ITS 1-4 (Aubin et al., 2005a). Among the 14 references of yeast characterisation listed in Table 1, Rhodotorula sp. was found dominant six times, both in marine and freshwater fish. Metschnikowia zobelii, Trichosporon cutaneum, and Candida tropicalis were also dominant in some marine fish. Most studies in freshwater concerned rainbow trout, or other Oncorhynchus spp. Debaryomyces hansenii was found dominant in four of these references, but Candida sp., Saccharomyces cerevisiae, and Leucosporidium sp. were also dominant in some rainbow trout intestinal samples. Cryptococcus sp., Pichia anomala, and Saccharomycodaceae were mentioned as minor occasional components of fish microbiota. Few colonies of Sporobolomyces sp. were also isolated from the intestine of healthy European sea bass fry (Gatesoupe, unpublished). The effort to characterise yeasts in fish is still meagre, and new studies will likely expand the diversity of taxons reported in fish microbiota.

\section{Pathogens}

Black yeast-like Exophiala spp. are parasites of fish, but their incidence is not discussed here, since they are clearly distinct from the yeasts hosted by healthy fish (Alderman, 1982; Reuter et al., 2003). Few types of yeast have been reported as responsible for disease in fish (Table 3). Metschnikowia bicuspidata var. bicuspidata caused mortality in chinook salmon fry fed infected Artemia franciscana, while the fry fed a commercial dry diet were not affected (Moore and Strom, 2003). These authors succeeded to reproduce the disease by intraperitoneal injection of the pathogen. This is an example of the risk of emergence of new diseases due to rearing practices, under artificial conditions and confrontation of living organisms that are not normally encountered in the wild. There were three cases of infection by Candida spp., two on salmon, and one on gilthead sea bream. The genus has also been found in healthy fish, even dominant in the gut of rainbow trout (Sakata et al., 1993; Gatesoupe et al., 2005a; Table 1). In their report of candidiasis in gilthead sea bream, Galuppi et al. (2001) emphasized that the yeast and other fungi may be potentially harmful in an immuno-compromised host, or in adverse environmental conditions. Sporidiobolaceae like Cryptococcus spp., Sporobolomyces salmonicolor and Trichosporon sp. also seem to be opportunistic, as they occasionally cause disease in fish. Most yeasts are likely harmless to healthy fish reared in good conditions, but new candidate probiotics should be carefully tested, while watching for any sign of casual mycosis. Even Saccharomyces cerevisiae var. boulardii may cause fungemia in diseased organisms, though the yeast is generally recognized as safe (Lherm et al., 2002; Cassone et al., 2003; Riquelme et al., 2003; Herbrecht and Nivoix, 2005). However, the risk of disease caused by candidate probiotics appears to be much more limited with yeast than with bacteria.

\section{Experimental colonisation of the intestine}

Andlid et al. (1995) demonstrated the ability of yeasts to colonise the intestine of rainbow trout and turbot. This was particularly evident after single administration either in the rearing 
water, or by force feeding (Table 4). More than 10 days after one introduction of Rhodotorula glutinis or D. hansenii HF1, the amount of yeast was much higher in the intestine than in the surrounding water. Most cells were counted in the transient content, but some adhered to the intestinal mucosa. The counts were particularly high in the feces, which likely contributed to establishing the yeast in the rearing system. The affinity of yeast for fish intestine was further studied by the same authors, who showed that autochthonous $S$. cerevisiae CBS 7764 and $D$. hansenii HF1 could adhere and grow on the intestinal mucus of rainbow trout as the sole food source (Vázquez-Juárez et al., 1997; Andlid et al., 1998). Vázquez-Juárez et al. (1993) showed that three strains isolated from flatfish adhered to several substrates (Rhodotorula rubra, $R$. glutinis, and Candida zeylanoides). Cell surface hydrophobicity was suspected to play a role in adhesion and colonisation (Vázquez-Juárez et al., 1994), as well as cell surface glycoproteins (Vázquez-Juárez, 1996) and heat shock proteins (Andlid et al., 1999). Allochthonous strains of $S$. cerevisiae were also retrieved associated with intestinal mucus in rainbow trout after overnight starvation, when the dietary yeast was daily supplied. The colonisation was maximum during the first month of feeding (Aubin et al., 2005a; Gatesoupe et al., 2005a; Waché et al., 2006). After five months of feeding, the yeast was still counted in high numbers in the intestinal content, but few were detected after overnight starvation (Gatesoupe et al., 2005b).

Allochthonous yeasts were tested on marine fish larvae, either $S$. cerevisiae var. boulardii CNCM I-1079 on pollack (Gatesoupe, 2002), or S. cerevisiae X2180 and D. hansenii HF1, isolated from rainbow trout, on European sea bass (Tovar-Ramírez et al., 2002, 2004). The counts of yeast retrieved in the larvae were ca. $10^{4}-10^{6} \mathrm{CFU} \mathrm{g} \mathrm{g}^{-1}$, on a body weight basis. These amounts were considerable in comparison with the results expressed on an intestinal weight basis for rainbow trout, but it was not possible to know whether the yeast cells were only transient in the gut, or whether the mucosa was actually colonised. In European sea bass larvae, microscopic observations of washed intestinal sections revealed the adherence of $S$. cerevisiae X2180 and D. hansenii HF1 in vitro (Tovar-Ramírez et al., 2002). The dietary yeast $S$. cerevisiae var. boulardii CNCM I-1079 was not detected in the intestine of European sea bass fingerlings, and the level of colonisation after 9 months was low (Gatesoupe, unpublished).

\section{Microbial competition}

After settlement in fish intestine, the yeasts have to compete with other microorganisms. Vázquez-Juárez et al. (1993) investigated putative factors for such competition in R. rubra, $R$. glutinis, and C. zeylanoides. The yeasts produced extracellular proteases and siderophores, and they bound lactoferrin. Iron availability is a key issue for fish microbiota (Gatesoupe et al., 1997), and such features may play a role for antagonism to some pathogens, the virulence of which is iron-dependent (Calvente et al., 1999). Yeasts are also known to produce killer toxins that can be used to control pathogenic fungi (e.g. Llorente et al., 1997; Marquina et al., 2001; Schmitt and Breinig, 2002).

Yeasts have been used as biocontrol agents for plant fungal diseases (e.g. Filonow et al., 1996; Petersson et al., 1999; Payne and Bruce 2001; Santos et al., 2004), and it would be worth investigating their potential against the numerous fungal diseases affecting fish (Alderman, 1982). Ducluzeau and Bensaada (1982) showed the antagonism of S. cerevisiae var. boulardii to Candida spp. settlement in murine intestine. Such observations in fish microbiota are still scarce, but there are two examples of competition among yeasts. The concomitant supplementation of D. hansenii HF1 and S. cerevisiae CBS 7764 in the diet of rainbow trout resulted in fecal colonisation by $D$. hansenii HF1, which corresponded to $95 \%$ 
of the isolates, though both strains were autochthonous (Andlid et al., 1995). Natural colonisation by $D$. hansenii was maximum in rainbow trout fry at day 20 post start feeding (Waché et al., 2006). In case of artificial colonisation by dietary allochthonous $S$. cerevisiae, which was maximum at day 10 , the later colonisation by $D$. hansenii was limited by a hundredfold, likely due to competition.

Yeast may be antagonistic to entero-pathogenic bacteria, e.g. due to adhesion of bacterial cells (Gedek, 1999) or by secreting proteases that inhibit toxins (Castagliuolo et al., 1999). Andlid et al. (1995) observed reduced numbers of bacteria when yeast colonisation peaked in rainbow trout intestine, though the effect of yeasts on bacteria associated in fish intestine is not clear. The proportions of the dominant strains was not the same with or without dietary addition of S. cerevisiae var. boulardii CNCM I-1079, but it was not possible to draw any general trend, due to high variability in time, and between locations (Aubin et al., 2005a; Gatesoupe et al., 2005a,b; Waché et al, 2006).

\section{Modulation of the immune response}

Yeast glucans have been extensively used as immunostimulants in fish (Sakai, 1999). Ortuño et al. (2002) suggested that lyophilised whole cells of a commercial strain of $S$. cerevisiae BMA64-1A could produce a more general immune response, due to other cell wall compounds besides ß-glucans, like mannoproteins, and chitin as a minor component. RNA extracts and partially autolysed brewers yeast may be also efficient (Sakai et al., 2001; Li and Gatlin, 2004). Siwicki et al. (1994) tested several immunostimulants on rainbow trout: lyophilised Candida utilis, lyophilised S. cerevisiae, ß-glucans (MacroGard ${ }^{\circledR}, ß-1,3 / 1,6-$ linked polymers of D-glucose, extracted and purified from baker's yeast, S. cerevisiae), deacylated chitin (Chitosan ${ }^{\circledR}, ß-1,4$-linked polymer of D-glucosamine), a premix of selenium and vitamins $\mathrm{C}$ and $\mathrm{E}$, and a premix of betaine and amino acids. The additives increased cellular immune response and immunoglobulin serum titres, and the most significant stimulations were generally observed with the two yeasts. After challenge with Aeromonas hydrophila, the best protection was obtained in rainbow trout fed either S. cerevisiae, ßglucans, or deacylated chitin, while C. utilis seemed less efficient. Quentel et al. (2005) did not observe a humoral response in rainbow trout fed dried active $S$. cerevisiae var. boulardii CNCM I-1079, but the treatment protected the trout against Yersinia ruckeri, while decreasing the number of asymptomatic carriers after challenge (Quentel et al., 2004). The response of channel catfish seemed different, when Duncan and Klesius (1996) compared the effects of ßD-glucan from barley and dried baker's yeast, S. cerevisiae. Cellular immunity was increased by both feed additives, but to a lesser extent with the yeast. In particular, glucan from barley, but not the yeast, stimulated the chemotactic response to Edwarsiella ictaluri exoantigen by macrophages and neutophils, and the chemiluminescent response to E. ictaluri by peritoneal exudate phagocytes. However, the fish were not protected against edwardsiellosis in a challenge experiment, even when they were fed glucan. In gilthead sea bream, cellular immunity was stimulated by dietary lyophilised $S$. cerevisiae in a dose-dependent manner, but the complement was not (Ortuño et al., 2002). Serum immunoglobulin M was also stimulated (Cuesta et al., 2004). The response of gilthead sea bream was modulated differently by a mutant strain $S$. cerevisiae fks-1, the cell wall of which was modified due to the inhibition of ß-1,3-D-glucan synthase, and thus enriched in mannoproteins and chitin (Rodríguez et al., 2003). The lysozyme activity was significantly increased after 2-4 weeks of feeding the modified yeast, while serum peroxidase and complement activity were depressed after 6 weeks. The effect of dietary yeast on cellular immunity was confirmed, but with some differences depending on whether the yeast was modified or not. Esteban et al. (2004) 
demonstrated that a glucan receptor was involved in phagocytosis by gilthead sea bream leucocytes, unlike the mannose receptor, which was required with the glucan receptor for maximal phagocytosis by murine macrophages (Giaimis et al., 1993). All these data seemed to confirm that ß-glucans may be the most important components to account for immunostimulation of fish by yeast. The specific interest of feeding whole yeast rather than cell wall extract seemed limited for immunostimulation, but that should be evaluated with further challenge experiments, as well as with field studies in fish farms. To my knowledge, the effect of yeast viability on fish immunity has not been tested, whereas it was demonstrated that immune responses of rainbow trout were different when probiotic bacteria were supplied either active or inactivated (Irianto and Austin, 2003; Brunt and Austin, 2005; Panigrahi et al., 2005). Taoka et al. (2006a) confirmed recently that the viability of probiotics affected the immune response of Nile tilapia fed a commercial preparation including $S$. cerevisiae, Bacillus subtilis, Lactobacillus acidophilus, and Clostridium butyricum (Alchem Poseidon ${ }^{\circledR}$; Alchem-Korea Co. Ltd., Wonju, Korea), but the specific importance of yeast viability was not considered.

\section{The effects of live yeasts on fish metabolism}

A commercial preparation of live $S$. cerevisiae and Lactobacilllus coagulans (Bioboost Forte ${ }^{\circledR}$, Lyka Labs. Ltd., Bombay) was used as a growth promoter for Indian carp fry. Mohanty et al. (1993) introduced the preparation in an experimental diet, but it was not possible to conclude any effect of the probiotic on Labeo rohita, due to the lack of a suitable control diet. The effect of growth promotion was shown in later experiments on Catla catla and Cirrhinus mrigala (Mohanty et al., 1996; Swain et al., 1996), though it was impossible to demarcate the respective efficiencies of the yeast and L. coagulans. S. cerevisiae was also tested on Paralichthys olivaceus, with Alchem Poseidon® (Taoka et al., 2006b). Again, it was not possible to discriminate the contribution of the yeast among the effects observed on water quality, growth, survival, immune response, or stress and disease resistance. However, the microorganisms might work synergistically in such consortia, and that may be worth further investigating. An example of synergetic effect appeared when pollack larvae were fed Artemia nauplii, which were treated first with live S. cerevisiae var. boulardii CNCM I-1079, then with Pediococcus acidilactici MA185 M (Gatesoupe, 2002). The pollack larvae grew better than those fed nauplii treated with one or no probiotic. All combinations are not necessarily efficient, and Quentel et al. (2004) noted that the double supplementation of a diet with S. cerevisiae var. boulardii CNCM I-1079 and P. acidilactici MA185 M lowered the protective effect on rainbow trout challenged with $Y$. ruckeri, in comparison with single treatments.

When S. cerevisiae was tested alone, growth and feed efficiency were improved in Israeli carp (S. cerevisiae cultured on grain media, Noh et al., 1994) and Nile tilapia (Biosaf®, SafAgri, Minnapolis, MN, Lara-Flores et al., 2003). In tilapia fed a control diet, survival and digestibility were reduced by increasing the population density, while this stress did not affect the groups treated with the yeast (Lara-Flores et al., 2003). Such effects were not observed in rainbow trout, but some increase in lipid accretion and red pigmentation of the flesh was noted by Aubin et al. (S. cerevisiae var. boulardii CNCM I-1079, 2005b).

Tovar-Ramírez et al. (2002) compared the effects of two yeasts on European sea bass larvae fed compound diets. $D$. hansenii HF1 improved survival, and vertebral conformation of the larvae, possibly due to the observed acceleration of the maturation of the digestive system. These effects were not observed with $S$. cerevisiae X2180, and the larvae grew better when they were fed a control diet, likely due to an inadequate way of introduction of the yeasts after 
feed processing, which deteriorated the physical properties of the pellets. Tovar-Ramírez et al. (2004) remedied this defect by introducing $D$. hansenii HF1 in the compound diet before pelletization. The new probiotic diet improved the growth of larval European sea bass, in addition to intestinal maturation, survival, and conformation of the larvae. These improvements were obtained with a dose of ca. $10^{6} \mathrm{CFU} \mathrm{g}^{-1}$ of diet, whereas a higher dose of $6 \times 10^{6} \mathrm{CFU} \mathrm{g}^{-1}$ was less efficient. Waché et al. (2006) observed that the maturation of the digestive system took place before day 20 post start feeding in rainbow trout fry, and the natural colonisation by $D$. hansenii was too late to accelerate the onset. In such conditions, the dietary supplementation of S. cerevisiae var. boulardii CNCM I-1079 since start feeding stimulated at day 10 the activity of three enzymes in the brush border membrane of the enterocytes (alkaline phosphatase, $\gamma$-glutamyl-transpeptidase, and leucine-amino-peptidase $\mathrm{N}$ ), but without any effect on growth. Another strain of S. cerevisiae NCYC Sc 47/g did not stimulate this early maturation. The effect of $S$. cerevisiae var. boulardii (Laboratoires Biocodex, Montrouge, France) on the digestive maturation in weanling rats was likely mediated by the endoluminal release of spermine and spermidine (Buts et al., 1994). Dietary spermine also induced intestinal maturation in European sea bass larvae (Péres et al., 1997). Consequently, polyamine secretion was a possible mediator for the effect of the yeast on rainbow trout fry (Waché et al., 2006). D. hansenii HF1 produced much more spermidine than S. cerevisiae X2180, and that might also account for the effects observed in European sea bass (Tovar-Ramírez et al., 2002).

More generally, the polyamines play a fundamental role in proliferating, fast growing and regenerating tissues, while their endogenous synthesis appears somewhat insufficient in healthy animals (Peulen et al., 2002). It is therefore possible that polyamine production by yeasts may explain at least partly the effect observed on fish growth and metabolism. That will need further research.

\section{Perspectives}

In summary, fish intestine appear to be an occasional niche for yeast colonisation. The risk of harmful invasion seems low, as long as fish are reared in good conditions. Yeast may be generally considered as commensal in fish gut, and possible benefits can be expected for the immune and the digestive systems of the host, though many questions remain open to optimise the effect on fish health.

The first strategic choice is either to favour the development of autochthonous yeast, or to introduce probiotic strains. Natural settlement appears somewhat unpredictable, even in rainbow trout, the most documented species for frequent occurrence of yeast in the intestine. Further investigation is required to clarify the conditions for such colonisation. Some prebiotics might be tested with a view to stimulate growth and activity of yeasts, either native, or deliberately introduced (Selvakumar and Pandey, 1999; Mitterdorfer et al., 2001; Vranesic et al., 2002).

When yeasts are introduced with feed, an actual intestinal colonisation may not be necessary in every case. For instance, Durand-Chaucheyras et al. (1998) noted that S. cerevisiae did not colonise lamb rumen, where the probiotic yeast stimulated the activity of some autochthonous microbes. Such microbial interactions have not been evidenced in fish, where yeasts rather act directly on the host. The probiotic dietary yeast was efficient in rainbow trout at five months, in spite of poor association with the intestine (Aubin et al., 2005a; Gatesoupe et al., 2005b). Even if the intestinal transit is relatively short in fish, it is sufficient for digestion, and likely for the release of active compounds from yeast cells. 
The question remains whether viability is a prerequisite for the beneficial effects on fish. Autoclaved yeast lost the effect on nutrient utilization by turkey (Bradley and Savage, 1995), but microbial metabolism was not affected in simulated ruminal fermentation (Oeztuerk et al., 2005). Yeast viability is not likely to affect immunomodulation, as long as it seems mediated by cell-wall components. The answer is less obvious if other compounds are involved, like polyamines (ter Steege et al., 1999), enzymes (García-González and Ochoa, 1999) and other soluble factors (Freitas et al., 2005). The issue is crucial towards better understanding of the modes of action, especially those targeting fish metabolism.

\section{References}

Alderman, D.J., 1982. Fungal disease of aquatic animals. In: Roberts, R.J. (Ed.) Microbial Diseases of Fish. Academic Press, London, pp. 189-242.

Andlid, T., Juárez, R.V., Gustafsson, L., 1995. Yeast colonizing the intestine of rainbow trout (Salmo gairdneri) and turbot (Scophtalmus maximus). Microb. Ecol. 30, 321-334.

Andlid, T., Vázquez-Juárez, R., Gustafsson, L., 1998. Yeasts isolated from the intestine of rainbow trout adhere to and grow in intestinal mucus. Mol. Mar. Biol. Biotechnol. 7, 115126.

Andlid, T., Blomberg, L., Gustafsson, L., Blomberg, A., 1999. Characterization of Saccharomyces cerevisiae CBS 7764 isolated from rainbow trout intestine. Syst. Appl. Microbiol. 22, 145-155.

Aubin, J., Gatesoupe, F.J., Labbé, L., Lebrun, L., 2005a. Trial of probiotics to prevent the vertebral column compression syndrome in rainbow trout (Oncorhynchus mykiss Walbaum). Aquacult. Res. 36, 758-767.

Aubin, J., Gatesoupe, F.J., Quentel, C., Labbé, L., Forraz, M., 2005b. Ofimer probiotic study on rainbow trout. III. Flesh quality assessment of rainbow trout (Oncorhynchus mykiss) submitted to probiotic treatment with Saccharomyces cerevisiae var. boulardii. In: Howell, B., Flos, R. (Eds.), Lessons from the Past to Optimise the Future, Aquaculture Europe 2005, Trondheim, Norway, 5-9 August 2005. EAS Special Publication, vol. 35. European Aquaculture Society, Oostende, Belgium, pp. 115-116.

Biswas, S.K., Yokoyama, K., Nishimura, K., Miyaji, M., 2001. Molecular phylogenetics of the genus Rhodotorula and related basidiomycetous yeasts inferred from the mitochondrial cytochrome b gene. Int. J. Syst. Evol. Microbiol. 51, 1191-1199.

Bradley, G.L., Savage, T.F., 1995. The effect of autoclaving a yeast culture of Saccharomyces cerevisiae on turkey poult performance and the retention of gross energy, and selected minerals. Anim. Feed Sci. Technol. 55, 1-7.

Bruce, J., Morris, E.O., 1973. Psychrophilic yeasts isolated from marine fish. Antonie van Leeuwenhoek 39, 331-339.

Brunt, J., Austin, B., 2005. Use of a probiotic to control lactococcosis and streptococcosis in rainbow trout, Oncorhynchus mykiss (Walbaum). J. Fish Dis. 28, 693-701.

Buts, J.P., De Keyser, N., De Raedemaeker, L., 1994. Saccharomyces boulardii enhances rat intestinal enzyme expression by endoluminal release of polyamines. Pediatr. Res. 36, 522-527.

Cahill, G., Walsh, P.K., Donnelly, D., 1999. Improved control of brewery yeast pitching using image analysis. J. Am. Soc. Brew. Chem. 57, 72-78.

Calvente, V., Benuzzi, D., de Tosetti, M.I.S., 1999. Antagonistic action of siderophores from Rhodotorula glutinis upon the postharvest pathogen Penicillium expansum. Int. Biodeter. Biodegrad. 47, 167-172. 
Carmichael, J.W., 1966. Cerebral mycetoma of trout due to a Phialophora-like fungus. Sabouraudia 5, 120-123.

Cassone, M., Serra, P., Mondello, F., Girolamo, A., Scafetti, S., Pistella, E., Venditti, M., 2003. Outbreak of Saccharomyces cerevisiae subtype boulardii fungemia in patients neighboring those treated with a probiotic preparation of the organism. J. Clin. Microbiol. 41, 5340-5343.

Castagliuolo, I., Riegler, M.F., Valenick, L., LaMont, J.T., Pothoulakis, C., 1999. Saccharomyces boulardii protease inhibits the effects of Clostridium difficile toxins A and B in human colonic mucosa. Infect. Immun., 67, 302-307.

Cuesta, A., Meseguer, J., Esteban, M.A., 2004. Total serum immunoglobulin M levels are affected by immunomodulators in seabream (Sparus aurata L.). Vet. Immunol. Immunopathol. 101, 203-210.

Ducluzeau, R., Bensaada, M., 1982. Effet compare de l'administration unique ou en continu de Saccharomyces boulardii sur l'établissement de diverses souches de Candida dans le tractus digestif de souris gnotoxéniques. Ann. Microbiol. (Inst. Pasteur) 133B, 491-501.

Duncan, P.L., Klesius, P.K., 1996. Dietary immunostimulants enhance nonspecific immune responses in channel catfish but not resistance to Edwardsiella ictaluri. J. Aquat. Anim. Health 8, 241-248.

Durand-Chaucheyras, F., Fonty, G., Bertin, G., Théveniot, M., Gouet, P., 1998. Fate of levucell SCI-1077 yeast additive during digestive transit in lambs. Reprod. Nutr. Dev. 38, 275-280.

Eriksson, O.E. (Ed.), 2006. Outline of Ascomycota. Myconet 12, 1-82.

Esteban, M.A., Rodríguez, A., Meseguer, J., 2004. Glucan receptor but not mannose receptor is involved in the phagocytosis of Saccharomyces cerevisiae by seabream (Sparus aurata L.) blood leucocytes. Fish Shellfish Immunol. 16, 447-451.

Filonow, A.B., Vishniac, H.S., Anderson, J.A., Janisiewicz, W.J., 1996. Biological control of Botrytis cinerea in apple by yeasts from various habitats and their putative mechanisms of antagonism. Biol. Control 7, 212-220.

Freitas, M., Axelsson L.G., Cayuela, C., Midtvedt, T., Trugnan, G., 2005. Indigenous microbes and their soluble factors differentially modulate intestinal glycosylation steps in vivo. Use of a "lectin assay" to survey in vivo glycosylation changes. Histochem. Cell. Biol. 124, 423-433.

Gadanho, M., Sampaio, J.P., 2002. Polyphasic taxonomy of the basidiomycetous yeast genus Rhodotorula: Rh. glutinis sensu stricto and Rh. dairenensis comb. nov. FEMS Yeast Res. 2, 47-58.

Galuppi, R., Fioravanti, M.L., Delgado Montero, M.L., Quaglio, F., Caffara, M., Tampieri, M.P., 2001. Segnalazione di due casi di micosi della vescica natatoria in Sparus aurata e Carassius auratus. Boll. Soc. Ital. Patol. Ittica 13, 26-34.

García-González, A., Ochoa, J.L., 1999. Anti-inflammatory activity of Debaryomyces hansenii Cu,Zn-SOD. Arch. Med. Res. 30, 69-73.

Gatesoupe, F.J., 2002. Probiotic and formaldehyde treatments of Artemia nauplii as food for larval pollack, Pollachius pollachius. Aquaculture 212, 347-360.

Gatesoupe, F.J., Zambonino Infante, J.L., Cahu, C., Quazuguel, P., 1997. Early weaning of sea bass larvae, Dicentrarchus labrax: the effect on microbiota, with particular attention to iron supply and exoenzymes. Aquaculture 158, 117-127.

Gatesoupe, F.J., Aubin, J., Quentel, C., Labbé, L., 2005a. Ofimer probiotic study on rainbow trout. IV. The settlement of intestinal microbiota in rainbow trout (Oncorhynchus mykiss) fry submitted to probiotic treatment. In: Hendry, C.I., Van Stappen, G., Wille, M., Sorgeloos, P. (Eds.), Larvi 2005, 4th Fish and Shellfish Larviculture Symposium, 5-8 
September 2005, Ghent University, Gent, Belgium. EAS Special Publication, vol. 36. European Aquaculture Society, Oostende, Belgium, pp. 180-183.

Gatesoupe, F.J., Aubin, J., Quentel, C., Labbé, L., Forraz, M., 2005b. Ofimer probiotic study on rainbow trout. II. Intestinal microbiota in rainbow trout (Oncorhynchus mykiss) submitted to probiotic treatment with Saccharomyces cerevisiae var. boulardii. In: Howell, B., Flos, R. (Eds.), Lessons from the Past to Optimise the Future, Aquaculture Europe 2005, Trondheim, Norway, 5-9 August 2005. EAS Special Publication, vol. 35. European Aquaculture Society, Oostende, Belgium, pp. 217-218.

Gedek, B.R., 1999. Adherence of Escherichia coli serogroup O 157 and the Salmonella typhimurium mutant DT 104 to the surface of Saccharomyces boulardii. Mycoses. 42, 261-264.

Giaimis, J., Lombard, Y., Fonteneau, P., Muller, C.D., Levy, R., Makaya-Kumba, M., Lazdins, J., Poindron, P., 1993. Both mannose and beta-glucan receptors are involved in phagocytosis of unopsonized, heat-killed Saccharomyces cerevisiae by murine macrophages. J. Leukoc. Biol. 54: 564-571.

Hatai, K., Egusa, S., 1975. Candida sake from gastro-tympanites of amago, Oncorhynchus rhodurus. Bull. Jpn. Soc. Sci. Fish. 41, 993.

Herbrecht, R., Nivoix, Y., 2005. Saccharomyces cerevisiae fungemia: An adverse effect of Saccharomyces boulardii probiotic administration. Clin. Infect. Dis. 40, 1635-1637.

Irianto, A., Austin, B., 2003. Use of dead probiotic cells to control furunculosis in rainbow trout, Oncorhynchus mykiss (Walbaum). J. Fish Dis. 26, 59-62.

Lara-Flores, M., Olvera-Novoa, M.A., Guzmán-Méndez, B.E., López-Madrid, W., 2003. Use of the bacteria Streptococcus faecium and Lactobacillus acidophilus, and the yeast Saccharomyces cerevisiae as growth promoters in Nile tilapia (Oreochromis niloticus). Aquaculture 216, 193-201.

Lherm, T., Monet, C., Nougiere, B., Soulier, M., Larbi, D., Le Gall, C., Caen D., Malbrunot, C., 2002. Seven cases of fungemia with Saccharomyces boulardii in critically ill patients. Intens. Care Med. 28, 797-801.

Li, P., Gatlin, D.M., 2004. Dietary brewers yeast and the prebiotic Grobiotic ${ }^{\mathrm{TM}}$ AE influence growth performance, immune responses and resistance of hybrid striped bass (Morone chrysops x M. saxatilis) to Streptococcus iniae infection. Aquaculture 231, 445-456.

Llorente, P., Marquina, D., Santos, A., Peinado, J.M., Spencer-Martins, I., 1997. Effect of salt on the killer phenotype of yeasts from olive brines. Appl. Environ. Microbiol. 63, 11651167.

Marquina, D., Barroso, J., Santos, A., Peinado, J.M., 2001. Production and characteristics of Debaryomyces hansenii killer toxin. Microbiol. Res. 156, 387-391.

Mitterdorfer, G., Kniefel, W., Viernstein, H., 2001. Utilization of prebiotic carbohydrates by yeasts of therapeutic relevance. Lett. Appl. Microbiol. 33, 251-255.

Moffitt, C.M., Mobin, S.M.A., 2006. Profile of microflora of the posterior intestine of chinook salmon before, during, and after administration of rations with and without erythromycin. N. Am. J. Aquacult. 68, 176-185.

Mohanty, S.N., Swain, S.K., Tripathi, S.D., 1993. Growth and survival of rohu spawn fed on liver based diet. J. Inland Fish. Soc. Indai 25 (2), 41-45.

Mohanty, S.N., Swain, S.K., Tripathi, S.D., 1996. Rearing of catla (Catla catla Ham.) spawn on formulated diets. J. Aquacult. Trop. 11, 253-258.

Moore, M.M., Strom, M.S., 2003. Infection and mortality by the yeast Metschnikowia bicuspidata var. bicuspidata in chinook salmon fed live adult brine shrimp (Artemia franciscana). Aquaculture 220, 43-57.

Mueller, G.J., Whisler, H.C., 1994. Fungal parasites of salmon from the Columbia river watershed. In: Mueller, G.J. (Ed.), Salmon saprolegniasis, Report to Bonneville Power 
Administration, Contract No. 1990BP02836, Project No. 199006100, (BPA Report DOE/BP-02836-1). University of Washington, Seattle, Washington, pp 163-188.

Muench, T.M., White, M.R., Wu, C.C., 1996. Visceral mycosis in chinook salmon (Oncorhynchus tschawytscha) due to Sporobolomyces salmonicolor. Vet. Pathol. 33, 238-241.

Newman, J.T., Cosenza, B.J., Buck, J.D., 1972. Aerobic microflora of the bluefish (Pomatomus saltatrix) intestine. J. Fish. Res. Bd. Canada 29, 333-336.

Noh, S.H., Han, K., Won, T.H., Choi, Y.J., 1994. Effect of antibiotics, enzyme, yeast culture and probiotics on the growth performance of Israeli carp. Korean J. Anim. Sci. 36, 480486.

Oeztuerk, H., Schroeder, B., Beyerbach, M., Breves, G., 2005. Influence of living and autoclaved yeasts of Saccharomyces boulardii on in vitro ruminal microbial metabolism. J. Dairy Sci. 88, 2594-2600.

Ohwada, K., Tabor, P.S., Colwell, R.R., 1980. Species composition and barotolerance of gut microflora of deep-sea benthic macrofauna collected at various depths in the Atlantic Ocean. Appl. Environ. Microbiol. 40, 746-755.

Ortuño, J., Cuesta, A., Rodríguez, A., Esteban, M.A., Meseguer, J., 2002. Oral administration of yeast, Saccharomyces cerevisiae, enhances the cellular innate immune response of gilthead seabream (Sparus aurata L.). Vet. Immunol. Immunopathol. 85, 41-50.

Panigrahi, A., Kiron, V., Puangkaew, J., Kobayashi, T., Satoh, S., Sugita, H., 2005. The viability of probiotic bacteria as a factor influencing the immune response in rainbow trout Oncorhynchus mykiss. Aquaculture 243, 241-254.

Patterson, T.F., McGinnis, M.R. (Eds.), 2006. Doctor Fungus. http://www.doctorfungus.org/imageban/help.htm\#a

Payne, C., Bruce, A., 2001. The yeast Debaryomyces hansenii as a short-term biological control agent against fungal spoilage of sawn Pinus sylvestris timber. Biol. Control 22, 22-28.

Pelczar, Jr., M.J., Reid, R.D., 1972. Microbiology. McGraw-Hill Book Company, New York, $948 \mathrm{pp}$.

Péres, A., Cahu, C.L., Zambonino Infante, J.L., 1997. Dietary spermine supplementation induces intestinal maturation in sea bass (Dicentrarchus labrax) larvae. Fish Physiol. Biochem. 16, 479-485.

Petersson, S., Jonsson, N., Schnürer, J., 1999. Pichia anomala as a biocontrol agent during storage of high-moisture feed grain under airtight conditions. Postharvest Biol. Technol. 15, 175-184.

Peulen, O., Deloyer, P., Dandrifosse, G., 2002. Maturation of intestinal digestive and immune systems by food polyamines. In: Zabielski, R., Gregory, P.C., Westrom, B. (Eds.), Biology of the Intestine in Growing Animals, Vol. 1. Elsevier, Amsterdam, pp. 145-167.

Pierotti, D., 1971. Su di un particolare episodio di micosi in Tinca tinca. Atti Soc. Ital. Sci. Vet. 25, 361-363.

Quentel, C., Gatesoupe, F.J., Lamour, F., Abiven, A., Baud, M., Aubin, J., 2004. Effects of oral administration of probiotics on the resistance of rainbow trout, Oncorhynchus mykiss, against Yersinia ruckeri, asymptomatic carriers and humoral immune parameters. In: $6^{\text {th }}$ Symposium on Fish Immunology, 26-29 May 2004, Åbo, Turku, Finland, Book of abstracts, The Nordic Society for Fish Immunology, p. 60.

Quentel, C., Gatesoupe, F.J., Aubin, J., Lamour, F., Abiven, A., Baud, M., Labbé, L., Forraz, M., 2005. Ofimer probiotic study on rainbow trout. I. Resistance against Yersinia ruckeri and humoral immune response of rainbow trout (Oncorhynchus mykiss) submitted to probiotic treatment with Saccharomyces cerevisiae var. boulardii. In: Howell, B., Flos, R. (Eds.), Lessons from the Past to Optimise the Future, Aquaculture Europe 2005, 
Trondheim, Norway, 5-9 August 2005. EAS Special Publication, vol. 35. European Aquaculture Society, Oostende, Belgium, pp. 380-381.

Reuter, R.E., Hutchinson, W., Ham, J., Davis, S., 2003. Exophiala sp. infection in captured King George whiting (Sillaginodes punctata). Bull. Eur. Assoc. Fish Pathol. 23, 128-134.

Ringø, E., Olsen, R.E., 1999. The effect of diet on aerobic bacterial flora associated with intestine of Arctic charr (Salvelinus alpinus L.). J. Appl. Microbiol. 86, 22-28.

Riquelme, A.J., Calvo, M.A., Guzman, A.M., Depix, M.S., Garcia, P., Perez, C., Arrese, M., Labarca, J.A., 2003. Saccharomyces cerevisiae fungemia after Saccharomyces boulardii treatment in immunocompromised patients. J. Clin. Gastroenterol. 36, 41-43.

Rodríguez, A., Cuesta, A., Ortuño, J., Esteban, M.A., Meseguer, J., 2003. Immunostimulant properties of a cell wall-modified whole Saccharomyces cerevisiae strain administered by diet to seabream (Sparus aurata L.). Vet. Immunol. Immunopathol. 96, 183-192.

Ross, S.S., Morris, E.O., 1965. An investigation of the yeast flora of marine fish from Scottish coastal waters and a fishing ground off Iceland. J. Appl. Bacteriol. 28, 224-234.

Roth, Jr., F.J., Ahearn, D.G., Fell, J.W., Meyers, S.P., Meyer, S.A., 1962. Ecology and taxonomy of yeasts isolated from various marine substrates. Limnol. Oceanogr. 7, 178185.

Sakai, M., 1999. Current research status of fish immunostimulants. Aquaculture 172, 63-92.

Sakai, M., Taniguchi, K., Mamoto, K., Ogawa, H., Tabata, M., 2001. Immunostimulant effects of nucleotide isolated from yeast RNA on carp, Cyprinus carpio L. J. Fish Dis. 24, 433-438.

Sakata, T., Oshiro, T., Teshima, S.I., 1993. Characteristics and fatty acid composition of yeast isolated from the intestines of rainbow trout Oncorhynchus mykiss. Mem. Fac. Fish. Kagoshima Univ. 42, 51-59.

Santos, A., Sánchez, A., Marquina, D., 2004. Yeasts as biological agents to control Botrytis cinerea. Microbiol. Res. 159, 331-338.

Schmitt, M.J., Breinig, F., 2002. The viral killer system in yeast: from molecular biology to application. FEMS Microbiol. Rev. 26, 257-276.

Selvakumar, P., Pandey, A., 1999. Comparative studies on inulinase synthesis by Staphylococcus sp. and Kluyveromyces marxianus in submerged culture. Bioresource Technol. 69, 123-127.

Sera, H., Kimata, M., 1972. Bacterial flora in the digestive tract of marine fish - I. Bacterial flora of fish, red sea bream snapper and crimson sea bream, fed three kinds of diets. Bull. Jpn. Soc. Sci. Fish. 38, 50-55.

Siwicki, A.K., Anderson, D.P., Rumsey, G.L., 1994. Dietary intake of immunostimulants by rainbow trout affects non-specific immunity and protection against furunculosis. Vet. Immunol. Immunopathol. 41, 125-139.

Stones, C.S., Mills, D.V., 2004. The use of live yeast and yeast culture products in aquaculture. Int. Aquafeed 7 (5), 28-34.

Sugita, H., Oshima, K., Tamura, M., Deguchi, Y., 1983. Bacterial flora in the gastrointestine of freshwater fishes in the river. Bull. Jpn. Soc. Sci. Fish. 49, 1387-1395.

Sugita, H., Miyajima, C., Iwata, J., Arai, S., Kubo, T., Igarashi, S., Deguchi, Y., 1988. Intestinal microflora of Japanese coastal fishes. Nippon Suisan Gakkaishi 54, 875-882.

Sugita, H., Miyajima, C., Sugiura, C., Iwata, M., Kato, S., Deguchi, Y., 1989. The intestinal microflora of Japanese migratory fish. J. Fish Biol. 35, 161-163.

Swain, S.K., Rangacharyulu, P.V., Sarkar, S., Das, K.M., 1996. Effect of a probiotic supplement on growth, nutrient utilization and carcass composition in mrigal fry. J. Aquacult. (Cent. Inst. Fresh Water Aquacult., Kausalyaganga, Bhubaneshwar, Orissa, India) 4, 29-35. 
Takashima, M., Sugita, T., Shinoda, T., Nakase, T. 2001. Reclassification of the Cryptococcus humicola complex. Int. J. Syst. Evol. Microbiol. 51, 2199-2210.

Taoka, Y., Maeda, H. Jo, J.Y., Kim, S.M., Park, S.I., Yoshikawa, T., Sakata, T., 2006a. Use of live and dead probiotic cells in tilapia Oreochromis niloticus. Fisheries Sci. 72, 755766.

Taoka, Y., Maeda, H. Jo, J.Y., Jeon, M.J., Bai, S.C., Lee, W.J., Yuge, K., Koshio, S., 2006b. Growth, stress tolerance and non-specific immune response of Japanese flounder Paralichthys olivaceus to probiotics in a closed recirculating system. Fisheries Sci. 72, 310-321.

ter Steege, J.C.A., Forget, P.P., Buurman, W.A., 1999. Oral spermine administration inhibits nitric oxide-mediated intestinal damage and levels of systemic inflammatory mediators in a mouse endotoxin model. Shock 11, 115-119.

Toranzo, A.E., Novoa, B., Romalde, J.L., Núñez, S., Devesa, S., Mariño, E., Silva, R., Martínez, E., Figueras, A. Barja, J.L., 1993. Microflora associated with healthy and diseased turbot (Scophthalmus maximus) from three farms in northwest Spain. Aquaculture 114, 189-202.

Tovar-Ramírez, D., Zambonino, J., Cahu, C. Gatesoupe, F.J., Vázquez-Juárez, R., Lésel, R., 2002. Effect of live yeast incorporation in compound diet on digestive enzyme activity in sea bass (Dicentrarchus labrax) larvae. Aquaculture 204, 113-123.

Tovar-Ramírez, D., Zambonino Infante, J., Cahu, C., Gatesoupe, F.J., Vázquez-Juárez, R., 2004. Influence of dietary live yeast on European sea bass (Dicentrarchus labrax) larval development. Aquaculture 234, 415-427.

Trust, T.J., 1975. Facultative anaerobic bacteria in the digestive tract of chum salmon (Oncorhynchus keta) maintained in fresh water under defined culture conditions. Appl Microbiol. 29, 663-668.

Valente, P., Ramos, J.P., Leoncini, O., 1999. Sequencing as a tool in yeast molecular taxonomy. Can. J. Microbiol. 45, 949-958.

Van Uden, N., Castello-Branco, R., 1963. Distribution and population densities of yeast species in Pacific water, air, animals and kelp off southern California. Limnol. Oceanogr. 8, 323-329.

Vázquez-Juárez , R., 1996. Factors involved in the colonization of fish intestine by yeasts. PhD thesis. University of Göteborg, Sweden.

Vázquez-Juárez, R., Andlid, T., Gustafsson, L., Wadström, T., 1993. The expression of potential colonization factors of yeasts isolated from fish during different growth conditions. Can. J. Microbiol. 39, 1135-1141.

Vázquez-Juárez, R., Andlid, T., Gustafsson, L., 1994. Cell surface hydrophobicity and its relation to adhesion of yeasts isolated from fish gut. Colloids Surfaces B: Biointerfaces 2, 199-208.

Vázquez-Juárez, R., Andlid, T., Gustafsson, L., 1997. Adhesion of yeast isolated from fish gut to crude intestinal mucus of rainbow trout, Salmo gairdneri. Mol. Mar. Biol. Biotechnol. 6, 64-71.

Vranesic, D., Kurtanjek, Z., Kurtanjek, Z., Santos, A.M.P., Maugeri, F., 2002. Optimisation of inulinase production by Kluyveromyces bulgaricus. Food Technol. Biotechnol. 40, 6773.

Waché, Y., Auffray, F., Gatesoupe, F.J., Zambonino, J., Gayet, V., Labbé, L., Quentel, C., 2006. Cross effects of the strain of dietary Saccharomyces cerevisiae and rearing conditions on the onset of intestinal microbiota and digestive enzymes in rainbow trout, Onchorhynchus mykiss, fry. Aquaculture 258, 470-478. 
Wheeler, D.L., Chappey, C., Lash, A.E., Leipe D.D., Madden, T.L., Schuler, G.D., Tatusova, T.A., Rapp, B.A., 2000. Database resources of the National Center for Biotechnology Information. Nucleic Acids Res. 28, 10-14.

Wilhelm, R., Heller, O., Bohland, M., Tomaschewski, C., Klein, I. Klauth, P. Tappe, W. Groeneweg, J., Soeder, C.J., Jansen, P., Meyer, W., 1998. Biometric analysis of physiologically structured pure bacterial cultures recovering from starvation. Can. J. Microbiol. 44, 399-404.

Yoshimizu, M., Kimura, T., Sakai, M., 1976a. Studies on the intestinal microflora of salmonids: I. The intestinal microflora of fish reared in freshwater and seawater. Bull. Jpn. Soc. Sci. Fish. 42, 91-99.

Yoshimizu, M., Kimura, T., Sakai, M., 1976b. Studies on the intestinal microflora of salmonids: V. The intestinal microflora of the anadromous salmon. Bull. Jpn. Soc. Sci. Fish. 42, 1291-1298.

Yoshimizu, M., Kimura, T., Sakai, M., 1980. Microflora of the embryo and the fry of salmonids. Bull. Jpn. Soc. Sci. Fish. 46, 967-975. 
Table 1

Natural occurrence of yeasts in the gastrointestinal tract of healthy fish

\begin{tabular}{|c|c|c|c|c|c|}
\hline Fish & Environment ${ }^{\S}$ & $\log (\mathrm{CFU} / \mathrm{g})$ & $\%$ microbial isolates & Yeast species* & Reference \\
\hline Synaphobranchus kaupi & Deep sea & $5-7$ & $50-90$ & - & Ohwada et al. (1980) \\
\hline Pleuronectes platessa, Platichthys flesus & Coastal & 2 & - & Rhodotorula sp. & Andlid et al. (1995) \\
\hline Atherinopis affinis littoralis & Coastal & $0-2$ & - & M.z., K.a. & Van Uden and Castello-Branco (1963) \\
\hline Beryx splenedens & Coastal & 5 & - & - & Sugita et al. (1989) \\
\hline Girella punctata & Coastal & 2 & - & - & Sugita et al. (1988) \\
\hline Pomatomus saltatrix & Coastal & - & 3 & Rhodotorula sp. & Newman et al. (1972) \\
\hline Tachurus symmetricus & Coastal & $1-5$ & - & M.z., $D$. & Van Uden and Castello-Branco (1963) \\
\hline Pagrus major, Evynnis japonica & Sea farm & $2-3$ & $3-19$ & - & Sera and Kimata (1972) \\
\hline Scophthalmus maximus & Sea farm & - & 4 & - & Toranzo et al. (1993) \\
\hline Scophthalmus maximus & Sea farm & - & - & Ca. zeylanoides & Vázquez-Juárez et al. (1993) \\
\hline Other species & Tropical island & - & - & C.t., R., Ca. & Roth et al. (1962) \\
\hline Other species & Estuar., coastal & - & - & T.c., Ca., R., H.a., H.v., D. & Roth et al. (1962) \\
\hline Marine fish & Marine & - & - & R., Ca., Cr., D., T. & Bruce and Morris (1973) \\
\hline Pseudorasbora parva & River & 6 & - & - & Sugita et al. (1983) \\
\hline Oncorhynchus keta & F.w. farm & - & 1 & - & Trust (1975) \\
\hline Oncorhynchus keta & F.w. farm & 5 & 34 & - & Yoshimizu et al. (1976b) \\
\hline Oncorhynchus masou & F.w. farm & $4-5$ & $84-100$ & - & Yoshimizu et al. (1976b) \\
\hline Oncorhynchus mykiss & F.w. farm & $2-4$ & - & S.c., D.h., R., Cr., L. & Andlid et al. (1995) \\
\hline Oncorhynchus mykiss & F.w. farm & $0-5$ & - & D.h., R., T. & Aubin et al. (2005a) \\
\hline Oncorhynchus mykiss & F.w. farm & $0-2$ & - & S.c. & Gatesoupe et al. (2005b) \\
\hline Oncorhynchus mykiss & F.w. farm & $0-4$ & - & Ca., L., D.h. & Gatesoupe et al. (2005a) \\
\hline Oncorhynchus mykiss & F.w. farm & $0-4$ & - & D.h. & Waché et al. (2006) \\
\hline Oncorhynchus tschawytscha & F.w. farm & 3 & 17 & - & Yoshimizu et al. (1976a) \\
\hline Oncorhynchus tschawytscha & F.w. farm & $0-4$ & $0-80$ & - & Moffitt and Mobin (2006) \\
\hline Salvelinus alpinus & F.w. farm & 3 & - & - & Ringø and Olsen (1999) \\
\hline
\end{tabular}

$\S$ Environment: estuar. Estuarine; f.w. fresh water

* Yeast species (dominant in bold): Ca. Candida sp.; C.t. Candida tropicalis; Cr. Cryptococcus sp.; D. Debaryomyces sp.; D.h. Debaryomyces hansenii; M.z. Metschnikowia zobelii; H.a. Hansenula (Pichia) anomala; H.v. Hanseniaspora valbyensis; K.a. Kloeckera apiculata; L. Leucosporidium sp.; S.c. Saccharomyces cerevisiae; R. Rhodotorula sp.; T. Trichosporon sp.; T.c. Trichosporon cutaneum. 
Table 2

Tentative taxonomy of yeast genera reported to occur in fish microbiota

\begin{tabular}{|c|c|c|c|c|c|}
\hline Phylum & Class & Order & Family & Genus & First report of occurence \\
\hline \multirow[t]{10}{*}{ Ascomycota } & \multirow[t]{9}{*}{ Saccharomycetes } & \multirow[t]{9}{*}{ Saccharomycetales } & Dipodascaceae & Yarrowia & Gatesoupe (unpublished) \\
\hline & & & Metschnikowiaceae & Metschnikowia & Van Uden and Castello-Branco (1963) \\
\hline & & & Saccharomycetaceae & Candida & Ross and Morris (1965) \\
\hline & & & & Debaryomyces & Ross and Morris (1965) \\
\hline & & & & Kluyveromyces & Gatesoupe (unpublished) \\
\hline & & & & Pichia $^{\S}$ & Roth et al. (1962) \\
\hline & & & & Saccharomyces & Andlid et al. (1995) \\
\hline & & & Saccharomycodaceae & Hanseniaspora & Roth et al. (1962) \\
\hline & & & & Kloeckera* & Van Uden and Castello-Branco (1963) \\
\hline & Chaetothyriomycetes & Chaetothyriales & Herpotrichiellaceae & Exophiala & Carmichael (1966) \\
\hline \multirow[t]{7}{*}{ Basidiomycota } & \multirow[t]{2}{*}{ Basidiomycetes } & Filobasidiales & Filobasidiaceae & Filobasidium & Gatesoupe (unpublished) \\
\hline & & Tremellales & Tremellaceae & Bulleromyces & Gatesoupe (unpublished) \\
\hline & \multirow[t]{5}{*}{ Urediniomycetes } & \multicolumn{2}{|l|}{ Leucosporidiales } & Leucosporidium & Andlid et al. (1995) \\
\hline & & Sporidiales & Sporidiobolaceae & Cryptococcus & Bruce and Morris (1973) \\
\hline & & & & Sporobolomyces & Muench et al. (1996) \\
\hline & & & & Rhodotorula & Bruce and Morris (1973) \\
\hline & & & & Trichosporon & Bruce and Morris (1973) \\
\hline
\end{tabular}

$\S$ formerly Hansenula; * anamorph of Hanseniaspora 
Table 3

Fish diseases caused by yeast infection

\begin{tabular}{llll}
\hline Pathogen & Fish & Symptoms & Reference \\
\hline Candida sake & Oncorhynchus rhodurus & Stomach distended with fluid & Hatai and Egusa (1975) \\
Candida sp. & Oncorhynchus tshawytscha & Internal lesions & Mueller and Whisler (1994) \\
Candida sp. & Sparus aurata & Swimbladder swollen with dense material & Galuppi et al. (2001) \\
Metschnikowia bicuspidata & Oncorhynchus tshawytscha & Mortality, systemic infection, necrosis & Moore and Strom (2003) \\
Cryptococcus spp. & Tinca tinca & Exophthalmos & Pierotti (1971) \\
$\begin{array}{l}\text { Cryptococcus sp. } \\
\text { Sporobolomyces salmonicolor }\end{array}$ & Oncorhynchus tshawytscha & Surface and internal lesions (swimbladder, kidney) & Mueller and Whisler (1994) \\
Trichosporon sp. & Oncorhynchus tshawytscha & Ascites, visceral mycosis & Muench et al. (1996) \\
& & & Mueller and Whisler (1994) \\
\hline
\end{tabular}


Table 4

Experimental colonisation of fish intestine by yeast

\begin{tabular}{|c|c|c|c|c|c|}
\hline \multirow[t]{2}{*}{ Fish } & \multirow[t]{2}{*}{ Introduction } & \multirow[t]{2}{*}{ Yeast } & \multicolumn{2}{|c|}{ Colonisation peak } & \multirow{2}{*}{ Reference } \\
\hline & & & $\log (\mathrm{CFU} / \mathrm{g})^{*}$ & $\begin{array}{l}\text { (days post start) } \\
\text { (d) }\end{array}$ & \\
\hline Rainbow trout & Single, in water & Rhodotorula glutinis & 3 (i.c.) & 17 & Andlid et al. (1995) \\
\hline Rainbow trout & Single, force feeding & Debaryomyces hansenii & 6 (feces) & 13 & Andlid et al. (1995) \\
\hline Turbot & Single, force feeding & Debaryomyces hansenii & 3 (s.c., i.c.) & 11 & Andlid et al. (1995) \\
\hline Rainbow trout & Feeding every 3 days & Debaryomyces hansenii & 9 (feces) & 53 & Andlid et al. (1995) \\
\hline Rainbow trout & Daily feeding & Saccharomyces cerevisiae & 4 (i.s.) & 10 & Waché et al. (2006) \\
\hline Rainbow trout & Daily feeding & Saccharomyces cerevisiae & 4 (i.s.) & 20 & Aubin et al. (2005a) \\
\hline Rainbow trout & Daily feeding & Saccharomyces cerevisiae & 3 (i.s.) & 31 & Gatesoupe et al. (2005a) \\
\hline Rainbow trout & Daily feeding & Saccharomyces cerevisiae & $0-1$ (i.s.) & 152 & Gatesoupe et al. (2005b) \\
\hline Rainbow trout & Daily feeding & Saccharomyces cerevisiae & 5 (i.c.) & 152 & Gatesoupe et al. (2005b) \\
\hline Pollack & Continuous feeding & Saccharomyces cerevisiae & 5-6 (b.w.) & 16 & Gatesoupe (2002) \\
\hline Sea bass & Continuous feeding & Debaryomyces hansenii & 4 (b.w.) & 31 & Tovar-Ramírez et al. (2002) \\
\hline Sea bass & Continuous feeding & Saccharomyces cerevisiae & 4 (b.w.) & 31 & Tovar-Ramírez et al. (2002) \\
\hline Sea bass & Continuous feeding & Debaryomyces hansenii & 5-6 (b.w.) & 20 & Tovar-Ramírez et al. (2004) \\
\hline Sea bass & Daily feeding & Saccharomyces cerevisiae & 3 (i.c., i.s.) & 278 & Gatesoupe (unpublished) \\
\hline
\end{tabular}

* i.c. intestinal content; s.c. stomacal content; i.s. emptied intestinal section ; b.w. body weight 